\title{
Retail Brand Equity: Measurements through Brand Policy and Store Formats
}

\author{
Magali Jara \\ LEMNA (Laboratoire d'Economie et de Management de Nantes-Atlantique), IUT Saint Nazaire, University of Nantes, Saint \\ Nazaire, France \\ Email: Magali.jara@univ-nantes.fr
}

How to cite this paper: Jara, M. (2018) Retail Brand Equity: Measurements through Brand Policy and Store Formats. American Journal of Industrial and Business Management, 8, 579-596. https://doi.org/10.4236/ajibm.2018.83038

Received: February 19, 2018

Accepted: March 17, 2018

Published: March 20, 2018

Copyright (c) 2018 by author and Scientific Research Publishing Inc. This work is licensed under the Creative Commons Attribution International License (CC BY 4.0).

http://creativecommons.org/licenses/by/4.0/

(c) (i) Open Access

\begin{abstract}
This research extends findings on the retail brand equity in measuring the impact of its antecedents on the loyalty to the brand and to the store. This article raises questions about the sustainable created value by standard retail brands mostly oriented to functional components. The retail branding policy and store formats moderate results. This research adopts a PLS-Path modeling to test the retail brand equity model and its variations and then to provide a synthetic calculation of the retail brand equity. Results show that the standard retail brand equity leads to the loyalty to the brand and to the store. It varies according to: 1) the store brand policy (store's own-named) appears to be a winning option maximizing the loyalty; 2) the "popular store" format-combining supermarket and department store-reinforces the sustainable relationship with customers because of the high level of service. By calculating scores, Carrefour brand maximizes the relationships within the model. This work focuses on French standard retail brands excluding other retail brands (such as generics or premium). Results also focus on one product category. The retailer's positioning variable extends previous contributions leading to more consistent results. This research is also focused on the antecedents of retail brand equity too less studied: Benefits (received from their consumption) and the packaging of the branded product are thus integrated. Hence, perspectives for practitioners are suggested.
\end{abstract}

\section{Keywords}

Retail Brand Equity, Retail Branding Policies, Retailer Positioning, Store Formats

\section{Introduction}

In 1996, Quelch and Harding [1] published their seminal article concerning the conflict between manufacturer brands and private labels. They clearly elicited 
the threats of retail brands to the leading national brands. Hence, innovation, communication and effective promotions are defined as the key factors to manage [2] [3]. Twenty years later, national brands are jeopardising the price positioning of standard retail brands while they are enhancing quality [4], i.e., the conflict is being reversed. Since 2008 number comments in professional circles about the price war among national brands have included the issue of retail brands. More recently, since 2014, French retailers (Auchan and Système U; Carrefour and Cora; Intermarché and Casino) have joined their forces to increase their bargaining power towards suppliers leading manufacturer brands to be more competitive. Their prices are actually decreasing and it raises the following questions: What value could standard retail brands and retailers deliver to customers? More precisely, in that context, is the standard retail brand equity (mostly based on functional components) sufficient to lead to the loyalty to the brand and to the store? Is it different between retailers (depending on their retail branding policy and their store format strategies)?

Retail brands are, however, the strategic tools of the food retailers. Since the Carrefour "Free Products" in 1976, several generations of retail brands have emerged [5], differentiating retailers, including their tangible and intangible values and symbols.

Actually, retail brands belong exclusively to retailers. As a consequence, if retailers clearly control the axes of communication on their brands, those could represent a powerful source of long-term value for customers. This value can only be achieved if retail brands are also, differentiated from other competing brands, involving, a high level of perceived quality ([6]. A Nielsen survey, in 2014, confirms that the quality of private labels is the primary factor of choice which is in line with previous research [7] [8] [9] [10] [11].

This "value-oriented" development of retail brands enables them to ultimately construct their brand equity and to endow with it a unique position in consumers' mind. It is becoming relevant to anchor this research within the retail brand equity theoretical framework. However, research conducted on it [7] [12] [10] [11] [13]) or on retail brand value [8] [14] [15]) are few because of their recency.

Brand equity concept emerged in the early 1980s. Farquhar (1989) [16] defined brand equity as "the added value with which a given brand endows a product". The seminal work of Aaker (1991) [17] and Keller (1993) [18] initially used the same theoretical marketing model and referred to consumers' perceptions. Keller's approach is broader, including "all perceptions about a brand as reflected by the brand associations held in consumer memory." Based on this conceptual framework, retail brand equity could be defined as "the differential effect the retail brand's knowledge on consumer's response to marketing of retail brands" (adapted from Keller, 1993 [18]). The positive consumer's response is based on building a strong, unique (or clearly distinct), positive and consistent image [18] and the marketing efforts of retailers. Increasingly, food and non-food retail brands are no longer reluctant to innovate. Such are the cases of 
Decathlon Starboard Fatigless swimwear stretching the limits of fatigue), Tesco (new flavors of sorbet with champagne for example, almond milk enriched with calcium as an alternative to cow's milk) or yet at Leclerc (a smoothie shower gel under the "Marque Repère" label).

Thus, if retail brands support the brand equity concept, they could potentially produce positive consequences on the customer's loyalty (to the brand and the store). This causal relationship has been suggested by several previous contributions. Binninger (2007) [19] partly extended this relationship (in terms of psychological determinants of consumers' attitudes to retail brands); Martos-Partal and Gonzales-Benito (2011) [15] measured this relationship in an international comparison, without identifying items of the retail brand image responsible for created value; Beristain and Zorrilla (2011) [7] then Diallo et al., (2015) [9] partially tested this impact by taking into account few store brand associations as antecedents of the retail brand equity, i.e., the price image and the perceived quality of the retail brand are the two determinants of store loyalty.

Our research forms part of the theoretical retail brand equity framework, better suited to current managerial questions. It addresses those strategic and tactical questions and expands the previous contributions dedicated to the retail brand equity. More precisely, three objectives lead this research: 1) To test the impact of retail brand equity antecedents (in taking into account all associations related to the branded product and to store service) on the loyalty to the retail brand and to the store; 2) To moderate results by taking into account the retail branding policy (store brand - store's own-named brands - store-banner brand like Carrefour brand from Carrefour, Monoprix brand from Monoprix vs. flagship retail brands-named differently from retailer but recognized as a retail brand like "Marque Repère" brand from E.Leclerc) and the retailer's positioning through the store format (hypermarkets vs. the "popular store"-supermarket and department store combined, similar to a mini American Target Store). Our paper is in line with Keller and his colleagues' work (2016) [14] by focusing on retailers' performance (moderated by the retail branding policy and the retailer's positioning) but it studies it through customers' perceptions on standard retail brands.

Actually, this research taking place in a French context, it becomes relevant and original to consider all various retailers' strategies towards their retail brands and their stores. Hence, the third objective is to calculate the retail brand equity for each retailer through a synthetic rate leading to appreciate the specific retail brand performance.

This paper is structured as follows. Firstly, it begins by synthetically describing the theoretical framework of the retail brand equity and exposes hypotheses. Secondly, it details the research design. Hence, results emerging from the structural model are moderated by the retail branding policy and the store format. Finally, contributions and limits are discussed leading to managerial and tactical implications. 


\section{From Generic/Economic Private Labels to Retail Brand Equity}

Previously, research on retail brands had particularly focused on the study of their image. The price image was a historical variable of the retail brand positioning [7] [9] [15], although it was not always the unique and the determinant factor in the retail brand purchase [12] [15]. Through their promotions, the effort of national brands on price narrows the price gap with standard retail brands; certain thematic and premium retail brands are sometimes more expensive than national brands (for example, Reflets de France of Carrefour). However, prior conceptualizations and measures of the standard retail brand image (positioned between generic/economic and premium retail brands) do not consider that they could create value while they represent an average on $30 \%$ of retailer turnover. It is therefore urgent to ascertain the axes of created value by them.

\subsection{The Retail Brand Image: Measures and Moderators}

In line with previous research in retailing, retail brands could be considered as a service brand meaning it is a final extension of the retailer [20]. Consumers may actually infer or deduce some of the associations of the retail brands image from both the brand and the store perceptions [7] [8] [11] [21]. This transfer reinforces the retail brand image in order to differentiate it from others (due to the specific attributes of the store). Dimitriadis (1993 [20]) evokes the difficulty in measuring the retailer equity, due to the lack of homogeneity of stores (different locally). Stores are places of exchange and proximity, whereas the retailer appears as distant and cold [22]. Thus, this research focuses on product dimensions and store service associations.

Previous research (see Table 1) showed that the retail brand performance varies according to two criteria, i.e., the category of products and the retail brand policy.

Table 1 provides a summary of consumers' behaviors towards retail brands

Table 1. Consumers' behaviors towards retail brand depending on the product category.

\begin{tabular}{|c|c|}
\hline References & Consumers' behaviors towards private labels \\
\hline & $\begin{array}{l}\text { Category criteria } \\
\text { Buy retail brands when: }\end{array}$ \\
\hline $\begin{array}{c}\text { Batra and Sinha (2000) [23] } \\
\text { DelVecchio (2001) [24] } \\
\text { Cuneo et al. (2012) [12] }\end{array}$ & Functional product \\
\hline Batra and Sinha (2000) [23] & $\begin{array}{l}\text { Perceived quality doesn't vary between national brands and } \\
\text { private labels. }\end{array}$ \\
\hline Batra and Sinha (2000) [23] & $\begin{array}{l}\text { Perceived risk is low. Functional risk is related to the retailer's } \\
\text { know-how in that psychological risk is both related to the } \\
\text { consequences of making a mistake and social image of the } \\
\text { consumer as well as financial risk. }\end{array}$ \\
\hline
\end{tabular}


according to the product category. Based on those numerous research, it emphasizes that consumers are likely to buy a retail brand when:

- the product is functional;

- the perceived risk is low;

- the competing brands are homogeneous in terms of perceived quality.

Furthermore, the retail brand policy also seems to be a moderating variable of the brand performance. Consumers accept higher prices for retail brands if they are signed with the retailer's name (namely store brand or stores' own-named or store-banner brand) and if it is not a me-too product of the leading brand (with similar packaging for instance). Few retail brands have equal rates of re-purchase or better rates than national [25]. Ngobo (2011) [26] tested the relationship between a store brand (stores' own-named) and the customer loyalty in comparison with another-named brand: "the association between the store's own-named relative private label shares and the customer's loyalty to that store is stronger than the association with the store's other-named relative private label share" (Ngobo, 2011, p.265 [26]). Jara and Cliquet (2012) [11] show that store brands have a greater potential of differentiation than other-named brands (or standalone brands) and flagship brands (brands are not signed with the retailer's name but identified as retail brands) since they cover a wider area of associations. Keller et al., (2016) [14] add that "retailers that are higher on brand equity are more likely to use store-banner branding on their premium PL tiers" (p.4) and this effect is weaker for the economy tier. But what about standard retail brands?

To our knowledge, only one research, has taken into account the role played by the store format in the created value of store brands [8]. Their results differ from supermarkets to hypermarkets concerning the influence of the store image in the building of the retail brand equity. Those results lead us to deepen the role played by the store format in the case of "popular store" (unstudied previously) and hypermarkets.

\subsection{Retail Brand Equity: Theoretical Model and Hypotheses}

According to the theoretical background, brand equity is defined by two components: the brand image (composed by strong, positive, unique and consistent associations) and the awareness [17] [18]. The marketing mass media communication supports the awareness. In France, retailers were unable to mobilize the mass media to assess their brand awareness (until 2007), that is why only the retail brand image appears, at this stage, to determine the repeat purchase behavior towards it.

According to Jacoby and Kyner, (1973) [27] and then Oliver (1999) [28], loyalty is based on three dimensions: cognitive, affective and conative. Through his shopping experience, the consumer develops believes about the brand and the store. Following this, such a positive attitude leads to the brand purchase (in the case of a positive experience). Specifically, this research means that loyalty is 
a consequence of the consumer's perceptions. It thus bears links with the contributions of Zeithaml et al., (1996) [29]; loyalty is formed from the consumer's perceptions about the brand and the store leading to the felt and future behavioral intentions.

Given this, it is useful to test the brand equity and specifically to test its ability to retain: 1) to the retail brand; 2) to the store. Our theoretical model includes the significant dimensions measured in previous research relating to the retail brand equity and the store loyalty [7] [8] [9] [11] [15]. Figure 1 describes it.

This model includes:

- Six independent latent variables-they are components of the retail brand equity: the packaging, the perceived price, the perceived quality, financial benefits, decision-making benefits and the store service. Those variables define the "value" perceived by consumers. They are both related to product items such as "low prices", the perceived quality, the packaging and benefits from the consumption [30].

- One dependent latent variable: the loyalty (to the retail brand and to the store).

Therefore, hypotheses are revealed:

H1. Associations related to the branded product and to store service form the retail brand equity and influence positively the loyalty to the retail brand and to the store; More precisely,

H1a. Packaging forms the retail brand equity and influences positively the loyalty to the retail brand and to the store;

H1b. Perceived price forms the retail brand equity and influences positively

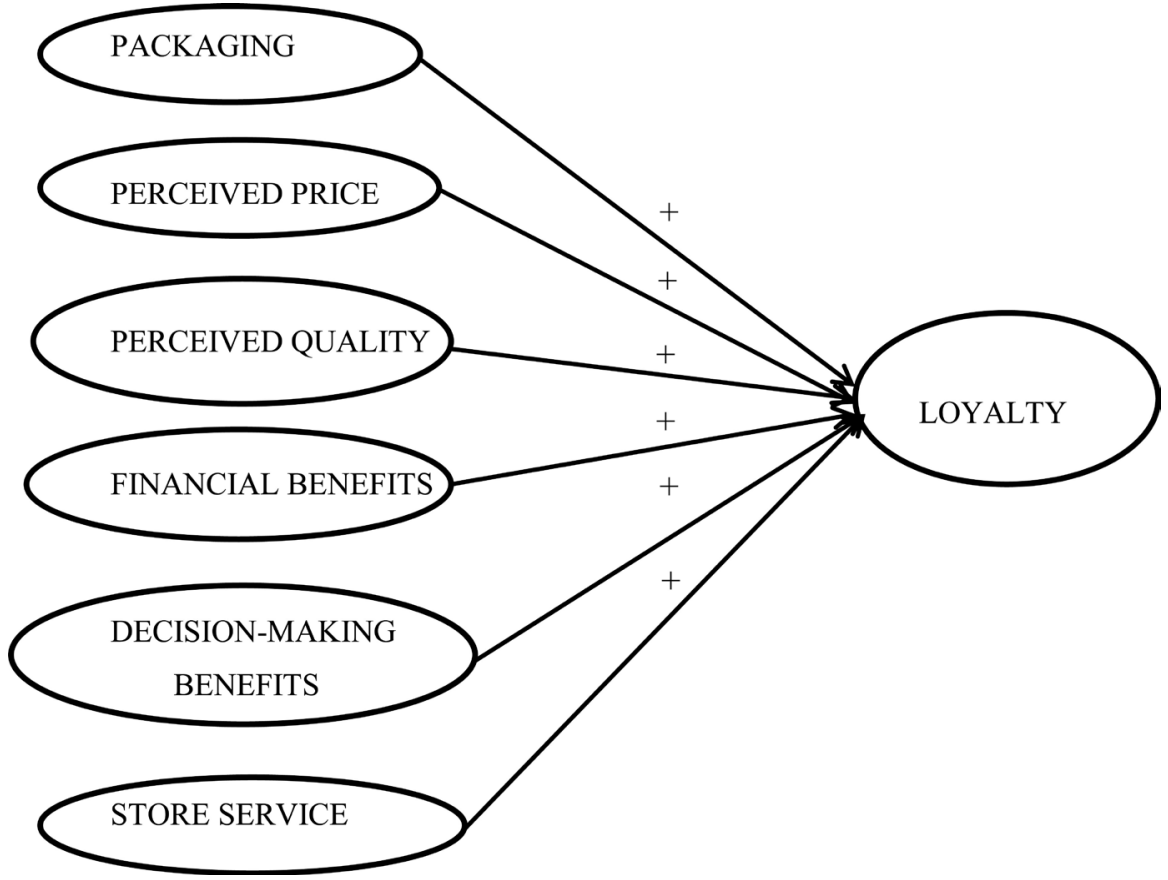

Figure 1. Theoretical model-antecedents of retail brand equity and consequences on loyalty. 
the loyalty to the retail brand and to the store;

H1c. Perceived quality forms the retail brand equity and influences positively the loyalty to the retail brand and to the store;

H1d. Financial benefits form the retail brand equity and influence positively the loyalty to the retail brand and to the store;

H1e. Decision-making benefits form the retail brand equity and influence positively the loyalty to the retail brand and to the store;

H1f. Store service forms the retail brand equity and influences positively the loyalty to the retail brand and to the store.

This model could be moderated by the retail branding policy and the retailer's positioning (through his store format). Hence,

$\mathrm{H} 2$. The retail brand equity is moderated both by the retail brand policy and the store format.

H3. The retail brand equity is maximized by the store brand policy (cumulating larger associations from the branded product and from the store) and the hypermarket format (its good value for money is in line with the original retail brands' positioning).

\section{Research Design}

Our research aims at testing the impact of the retail brand equity on the loyalty (to the brand and to the store) leading to:

- select standard retail brands: their managerial issue is more important due to the current events, their sales volume (higher than premium retail brands) and their potential of differentiation is higher than generic/economic private labels.

- measure the image of each retail brand (cognitive dimensions);

- measure the service of each store (cognitive dimensions);

- measure behavioral and emotional components of the loyalty to the retail brand by intentions to re-purchase and to the store and by the consumer's feelings towards it.

\subsection{Research Objects}

Based on previous research, the retail brand builds its brand equity from associations of the branded product and those of the store. In addition, two criteria are used: 1) the first is related to the branded product: the retail branding policy; 2) the second is related to the store format (hypermarket vs. "popular store").

Thus, three standard retail brands were considered: Carrefour brand (store brand sold in hypermarket), "Marque Repère" brand from E.Leclerc (flagship retail brand sold in supermarket and hypermarket E.Leclerc) and Monoprix brand (store brand sold in "popular store").

The choice of those retail brands is also assessed under the principal component analysis shown in Figure 2. Two dimensions emerge: the original retail brand assets (comprising the perceived price, the packaging and decision-making benefits) and the value for money (consisting of perceived quality and financial 


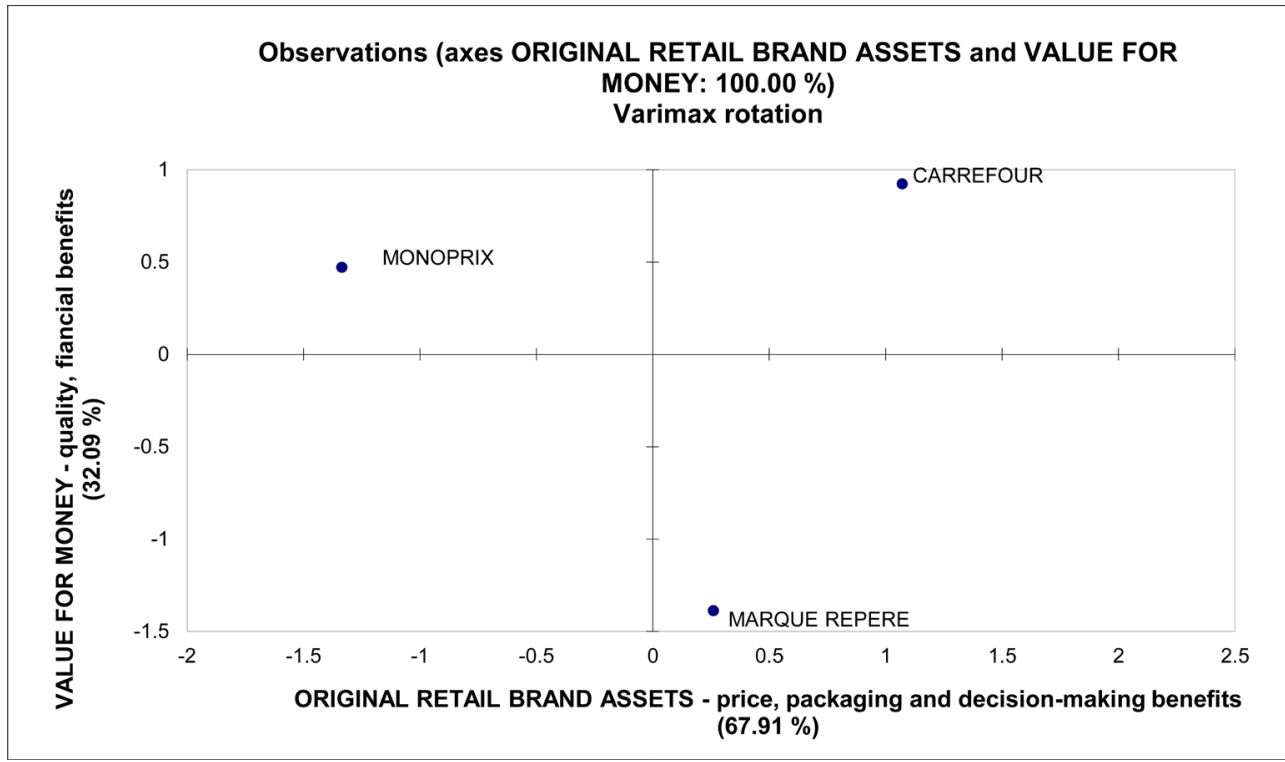

Figure 2. Retail brands positioning (XLSTAT software).

benefits variables). The Varimax rotation ensures the independence of the components and their readability by clearly assigning variables to their component.

Based on this factorial plan, the interest of the selection emerged by revealing those objects from three different positions. The three projected retail brands occupy distinct positions according to their branding policy and their mix retailing. In fact, the positioning of the Carrefour brand and Marque Repère (Leclerc) are opposite on the axis "value for money" (Carrefour simultaneously delivering a higher level of perceived quality and financial benefits than the Marque Repère), while Monoprix negatively occupies only the "original retail brand assets" axis. It therefore does not reflect the perceived positioning of the original standard retail brands. However, the relevance of this choice will be appreciated in the comparison of following structural models. Those typologies also corroborate different mix-retailing of retailers (the assortment, the price policy, the communication and the store atmosphere) depending on if it involves a hypermarket or a "popular store". Given this, the building of the brand equity and its effects on the loyalty should vary. The square cosines indicate the quality of the brands projections on axes (see appendix).

A single category of products is selected: self-service deli meats (ham, pâté...). This category bears some interest in this research because:

- there are less perceived quality differences between national brands and retail brands (related to previous research on retail brand performance according to the product category);

- those products represent frequent purchases, which reinforce the knowledge and familiarity of the respondent.

\subsection{Sample Selection}

Familiar consumers of their retail brands and who are loyal to the store (owning 
the store loyalty card) were interviewed. Actually, this familiarity leads to verify the quality of responses and to ensure the internal validity (since these consumers are better able to assess the relevant object on a set of specific criteria) and it is a necessary prerequisite for measuring loyalty. The sample is finally purposely not segmented according to individual criteria because previous research dedicated to retail brands have shown no unanimity about the buyer profile: the majority does not identify a causal link between individual characteristics of consumers and the retail brand purchase, especially since the product category is based on a low involvement [31].

The theoretical model is tested by using a PLS-Path modeling. This model, developed by Wold (1982) [32] and extended more than ten years ago [33], consists of estimating the parameters of the model by a succession of simple and multiple regressions based on the relationships between the latent variables ("internal" or structural model) and the manifest variables ("external" or measurement model). It is recommended to [34]:

- simultaneously measure causal relationships within a structural model with a small sample (120 observations);

- estimate behaviors;

- include formative constructs in the model;

- maximize the created value by acting on specific factors within the model.

Data were collected through a questionnaire (administered face-to-face). 120 familiar and loyal customers to the store (owners of the store loyalty card and making frequent purchases in the store-Table 2) were interviewed.

Variables were measured by a Likert five-point scale and are detailed in Table 3.

Table 2. Number of respondents.

\begin{tabular}{cc}
\hline & Number of respondents \\
\hline Carrefour customers buying the retail brand & 37 \\
Leclerc customers who buying the retail brand & 42 \\
Monoprix customers who buying the retail brand & 41 \\
Total & 120 \\
\hline
\end{tabular}

Table 3. Latent and observed variables.

\begin{tabular}{cl}
\hline Latent variables & \multicolumn{1}{c}{ Observed variables (Likert scale from 1 to 5) } \\
\hline $\begin{array}{c}\text { Perceived price } \\
\text { Perceived quality }\end{array}$ & Adequate price, low price. \\
Packaging & Good, high, good value for money. \\
Financial benefits & "Thanks to the retail brand, I get a good deal"; "Retail brands enable me to save money". \\
"Retail brands make it easier for me to choose"; "retail brands save me time because I know that this retail \\
brand is middle range". \\
Cleanness and modernity of the store; retail brand visibility on shelves, Retail brand in-store visibility; rigor of \\
merchandising; staff in contact (skills and availability). \\
Loyalty (to the brand and store) & Intent to buy the retail brand; "I feel I am loyal to my store".
\end{tabular}


Confirmatory factor analyses build the seven latent variables of the model.

\subsection{Model Validation}

The Rho Dillon-Goldstein and the convergent validity of measures with their average variance extracted $(>0.5)$ ensure the reliability of the scales (after the bootstrap procedure). Results are described in Table 4 and show a validation of the six latent variables.

The store service variable has been validated according to the Diamantopoulos and Winklhofer method (2001) [35], which is specifically adapted to the validation of formative latent variables. It is detailed as follows:

1) An analysis of correlations and weight measurement items in the latent variable: at this stage, an item is deleted whenever there is a sign reversal between its weight and its correlation to the latent variable.

2) Study of collinearity between the items of measurement: the "excessive" correlation between the items is unwanted as it prevents legible reading of the influence of each on the latent variable.

3) The external validity of the index: this is to show that the measurement items and their respective correlations are built more solidly than another built model.

The observed variables of each latent variable are highly heterogeneous in their causes and reveal implicitly two multidimensional components. Weak statistical indicators such as Cronbach's alpha (below 0.4 for both latent variables) confirm that those constructs cannot be one-dimensional.

Table 5 shows that the model is validated, since all relationships are significant. The components of the retail brand equity represent actually antecedents

Table 4. Reliability and constructs convergent validity (XLSTAT PLSPM software).

\begin{tabular}{ccc}
\hline Latent variables & D.G. Rho & Average of variance extracted \\
\hline PACKAGING & 0.817 & 0.593 \\
FINANCIAL BENEFITS & 0.950 & 0.905 \\
DECISION-MAKING BENEFITS & 0.943 & 0.891 \\
PERCEIVED PRICE & 0.822 & 0.692 \\
PERCEIVED QUALITY & 0.902 & 0.751 \\
LOYALTY & 0.760 & 0.593
\end{tabular}

Table 5. Statistic indicators-Goodness of fit (XLSTAT PLSPM software).

\begin{tabular}{ccc}
\hline GoF & GoF (Bootstrap) & $\mathrm{R}^{2}-F(15,289) \operatorname{Pr}>F: 0.000$ \\
\hline Absolute $=0.516$ & 0.544 & \\
Relative $=0.905$ & 0.875 & $0.510\left(\mathrm{R}^{2}\right.$ bootstrap $)$ \\
External model $=0.985$ & 0.973 & \\
Internal model $=0.919$ & 0.899 & \\
\hline
\end{tabular}

Bootstrap-500 re-sampling. 
of the loyalty to retail brands and store.

All statistic indicators show that constructs and relationships within them are validated.

\section{Results}

The retail brand equity model is at first validated. Moderators (retail brand policy and store format) precise then those results for each retail brand.

\subsection{Standard Retail Brand Equity Exists and Increases Loyalty}

Table 6 shows that the created value by standard retail brands-building a sustainable relationship with the retail brand and the store is explained in the quantitative order by:

1) A positive store service: $29.8 \%$ of created loyalty;

2) A level of perceived quality: $26 \%$;

3) Financial benefits: $15.8 \%$;

4) An appealing, informative and practical packaging: $8.1 \%$;

5) A short decision-making process: 5.5\%;

6) An adequate level of prices: $2.6 \%$.

Those statistic validations confirm that the standard retail brand equity exists. In other words, retail brand equity antecedents (packaging, perceived price, perceived quality, financial benefits, decision-making benefits and store service) influence positively the loyalty to the retail brand and to the store. H1a, H1b, H1c, H1d, Hle and H1f are supported. Note that store service and the perceived quality are the two key factors of the created value to customers. Clearly customers emphasize functional components.

\subsection{Moderators: Retail Brand Policy and Store Format}

By testing three distinct models incorporating two criteria of variation (the retail brand policy and the store format), more accurate results emerge. In fact, for each of the three retail brands, the sustainable relationship with the consumer is built through different levers in accordance with the marketing policy of its brand. Table 7 summarizes those results.

Based on Table 7, the retail brand equity depends on the retailer's positioning. In other words, the loyalty is moderated by the retail brand policy and the store format leading to three different retail brand equity models. Multi-group tests (between these three retail brands groups) confirmed that there is mostly no significant difference between groups regarding path-coefficients, correlations and the Goodness of fit. $\mathrm{H} 2$ is supported.

Retail brands are service brands. The store service builds the brand equity of the three studied retail brands. Systematically, the value created by retail brands depends on the store service. The latter variable is considerable and decisive in the case of the "popular store" (53.7\% of the loyalty is explained by store service). This is not surprising because of the high level of service offered in this 
Table 6. Path coefficients (XLSTAT PLSPM software).

\begin{tabular}{ccccccc}
\hline & $\begin{array}{c}\text { PERCEIVED } \\
\text { QUALITY }\end{array}$ & $\begin{array}{c}\text { STORE } \\
\text { SERVICE }\end{array}$ & PACKAGING & $\begin{array}{c}\text { FINANCIAL } \\
\text { BENEFITS }\end{array}$ & $\begin{array}{c}\text { DECISION-MAKING } \\
\text { BENEFITS }\end{array}$ & $\begin{array}{c}\text { PERCEIVED } \\
\text { PRICE }\end{array}$ \\
\hline Path coefficient & 0.260 & 0.298 & 0.081 & 0.158 & 0.055 & 0.026 \\
\hline
\end{tabular}

Table 7. Specific models for each retail brand.

\begin{tabular}{|c|c|c|c|}
\hline & CARREFOUR & MARQUE REPERE & MONOPRIX \\
\hline $\mathrm{R}^{2}$ (Bootstrap-500) & 0.768 & 0.711 & 0.772 \\
\hline Goodness of Fit after bootstrap (absolute and relative) & 0.655 and 0.839 & 0.638 and 0.811 & 0.612 and 0.802 \\
\hline & 1) Store service & 1) Store service & 1) Store service \\
\hline Components increasing loyalty-key factors of the & 2) Perceived price & 2) Decision-making benefits & 2) Financial benefits \\
\hline created value & 3) Perceived quality & 3) Financial benefits & 3) Decision-making benefits \\
\hline & 4) Financial benefits & 4) Perceived price & 4) Packaging \\
\hline $\begin{array}{c}\text { Carrefour model } \\
\text { Loyalty rate }=\begin{array}{c}4.32 / 5 \text { (obtained by Likert scale means } \\
\text { on each construct })\end{array}\end{array}$ & \multicolumn{3}{|c|}{$\begin{array}{l}44.7 \% \text { store service } \%+26.2 \% \text { perceived price }+13.4 \% \text { perceived quality }+12.7 \% \\
\text { financial benefits }+4.4 \% \text { decision-making benefits }+2.3 \% \text { packaging. }\end{array}$} \\
\hline $\begin{array}{c}\text { Marque Repère model } \\
\text { Loyalty rate }=\begin{array}{c}3.18 / 5 \text { (obtained by Likert scale means } \\
\text { on each construct })\end{array}\end{array}$ & \multicolumn{3}{|c|}{$\begin{array}{l}41 \% \text { store service }+39.3 \% \text { decision-making benefits }+12.5 \% \text { financial benefits }+11.5 \% \\
\text { perceived price }-7.1 \% \text { perceived quality }-3.9 \% \text { packaging. }\end{array}$} \\
\hline $\begin{array}{c}\text { Monoprix model } \\
\text { Loyalty rate }=3.27 / 5 \text { (obtained by Likert scale means } \\
\text { on each construct })\end{array}$ & \multicolumn{3}{|c|}{$\begin{array}{l}53.7 \% \text { store service }+20.3 \% \text { financial benefits }+16 \% \text { decision-making benefits }+15.8 \% \\
\text { packaging }+15.6 \% \text { perceived quality }-22.3 \% \text { perceived price. }\end{array}$} \\
\hline
\end{tabular}

store format.

For each retailer's positioning, specific components of retail brand equity. The components of the retail brand equity are fully coherent with the operational marketing of retailers.

1) Thus, in the case of Carrefour: the created value depends on the perceived price $(26.2 \%$ of the loyalty is built by the perceived price) and the perceived quality of its brand (13.4\%). This result illustrates the positive feedback from the repositioning of the brand on its price image since 2001. Suffering from a high price image in comparison with that of Leclerc, the company decided to change it by creating a generic/economic retail brand namely Numero 1, and to communicate more on this axis. Moreover, the perceived quality is the primary development of the retailer and of its brand-the Carrefour Quality Channel celebrated its $10^{\text {th }}$ anniversary in 2012 and attained 449 channels worldwide. This channel responds to consumer's expectations in terms of food safety, freshness, taste, authenticity (traditional know-how) and respect for the environment. Carrefour finally possesses an internal panel of consumers to test new products and maximize the quality of its brand. The retailer is deeply involved in the quality development of his brand.

2) Marque Repère: the created value is explained by the decision-making benefits (39.3\% of the loyalty) and financial benefits (12.5\%). This result reflects the 
brand strategy of the Leclerc consortium's objectives. Marque Repère is endeavoring to become a range marker to facilitate consumer choice. Price is historically the differentiation axis of the Marque Repère (Leclerc wanted it to be the new marker before the arrival of the Euro).

3) Monoprix brand: the created value is defined by the store's service $(53.7 \%$ of loyalty), a higher price (-22.3\%), the decision-making benefits (16\%), an appealing packaging (15.8\%) and the high level of perceived quality (15.6\%). However, the high level of prices destroys the sustainable relationship established in the model because it fails to comply with the expected item of "adequate price" (concerning standard retail brands). For this reason, this variable is negative in the Monoprix model (it destroys up to $22.3 \%$ of loyalty). This result is nevertheless consistent with both the positioning of this "popular store" and the "pull" brand strategy; unlike the two other hypermarkets-the adequate price variable being the key factor of their brand (in agreement with the positioning of these two discount hypermarkets). Monoprix has chosen to position its retail brand on the quality axis, the service and the innovation (for instance, products and stores like Dailymonop' or the walk-in). The location of its stores in high city illustrates this value-oriented positioning (stores are only present in $85 \%$ of towns with over 50,000 inhabitants); such is the case of its many partnerships like Mellow Yellow, American Retro for fashion. Monoprix was also one of the first retail brands to develop its organic ranges, ethics and sustainable developments, that today feature about 2000 products. More recently, Monoprix has transgressed the original exclusivity of the retail brand by referencing it on websites such as Amazon, La Redoute, Brandalley or MonShowRoom.com. Those examples show the perceived credibility of the Monoprix brand, leading to conceptualize its brand equity, not in the field of retail brands but in the manufacturer brands framework.

Finally, note the minor role assigned to the packaging. This finding is due to the product chosen (self-service deli). The attractiveness of the packaging plays a minor role in functional purchases.

By calculating synthetic rate for each retail brand (Table 7) the retail brand performance varies depending on the retail branding policy and the store format.

The retailer's positioning maximizes sustainable relationship with the consumer. Only the Carrefour brand still has positive factors building its relationship with the consumer, while for the two other retail brands, certain factors are negative (perceived price for Monoprix, perceived quality and packaging for Marque Repère) and potentially destroy the relationship. Thus the Carrefour brand has the highest loyalty rate (4.32/5 against 3.18/5 for the Marque Repère and 3.27/ 5 for the Monoprix brand). To conclude based on the large number of components building retail brand equity and ultimately its best performance rates, the Carrefour brand creates a sustainable relationship with its customers through operational marketing policies that are consistent with the retailer positioning. It represents the most efficient retail brands (in terms of the differen- 
tiated image and the loyalty) regarding the number of positive levers. $\mathrm{H} 3$ is supported.

\section{Conclusion, Discussion and Implications}

This article provides developments about the sustainable created value by standard retail brands (mostly oriented to functional components) in a price war against national brands. This research extends findings on the retail brand equity by measuring the impact of its antecedents on the loyalty to the brand and to the store. Testing one of the theoretical models of the retail brand equity [11], our results corroborate previous contributions. They point out that the standard retail brand equity exists from combinations of the associations related to the branded product and to the store service [7] [11] [13]. Within this context, the standard retail brand equity could be defined in quantitative order by:

1) A positive store service: $29.8 \%$ (created loyalty to the brand and the store is explained by a level of $29.8 \%$ store service);

2) A level of perceived quality: $26 \%$;

3) Financial benefits: $15.8 \%$;

4) An attractive, informative and practical packaging: $8.1 \%$;

5) A short decision-making process: 5.5\%;

6) A level of adequate prices: $2.6 \%$.

All of those components influence the loyalty both to the retail brand (repeat purchases) and to the store. They represent clearly differentiating axes to create a specific value to consumers.

To maintain the heterogeneous reality of retail brands, the model has been moderated by the retail branding policy-the store brand (its name is the same as the retailer's name) appears to be a winning option because it maximizes the brand and the store loyalty.

Based on those results (relationships within the model are all significant), standard retail brands have built a sustainable relationship with consumers. Interestingly, it is confirmed that retail brands surpass the store loyalty. This result corroborates and extends previous contributions using some of the same variables in their retail brand equity model [7] [9] 2011 [15].

Our research also shows that building the standard retail brand equity clearly reflects the strategies of stores; retailers will perform marketing of their brands by including them consistently in the overall strategy of the firm. In other words, the decisive component of the standard retail brands value creation differs from one brand to another. This brand equity changes according to the store format: the "popular store" intensifies the sustainable relationship with customers. This result may encourage retailers to develop their convenience format in the city center offering a mix-retailing approaching that of the "popular store".

Finally, by calculating the performance scores (estimated by the re-purchase of the retail brand and the loyalty felt by the customer towards the store), it seems that the hypermarket brand strategy maximizes sustainable relationship 
with customers (in the cases of standard retail brands in the self-service deli category). In the specific case of this research, the Carrefour brand maximizes the relationships within the model. Those results thus underline the importance of the discount in building a sustainable relationship with customers. It is useful here to show that the brand value can also be achieved through a discount strategy if and only if it is consistent with the original retailer's positioning.

Choosing a product category (self-service deli), however, is a limitation to the work. One class of products has been selected which can hardly be applied to the entire range. It is a prospect of future research and encourages us to continue this work by extending it to other categories (Cuneo et al., 2012) in order to improve external validity. In addition, this category explains the minor role played by the packaging variable.

Another path for development will measure the impact of the standard retail brand equity on the valuation of retailer equity. This issue has prompted too little attention to date (to our knowledge, only the works of Fleck and Nabec (2010) [36] and Kremer and Viot (2012) [37] suggest a conceptualization and measurement of the retailer equity).

Results of this research encourage retailers to pursue their marketing efforts in their brands. Until now, they have responded to customers' expectations, encouraging them to buy again, and to be loyal to their store. This virtuous cycle of building a sustainable relationship, is only possible if the retail brand strategy is fully consistent with the retailer positioning. Hence, by operating the determinants of the sustainable relationship, specific to each brand, each retailer could maximize his retail brand value. This result complies with and develops the contributions of Beristain and Zorrilla (2011 [7]).

Our paper finally highlights specific items for each retail brand, thus facilitating the tactical decision of the brand. For example:

1) In the case of the brand Carrefour, it would be worthwhile pursuing the efforts on the convenience store to maximize the Carrefour brand equity. The size of the store is a key factor in the retail brands success so why not propose a convenience store dedicated exclusively to Carrefour brand and strong manufacturer brands? Thus, the variables such as perceived price and perceived quality would be maximized by this kind of store. The launch of Carrefour Bio stores is one example.

2) In the case of Monoprix, thinking about the expansion of its retail brand to a lower price range would be relevant. By creating a low price retail brand, the firm could maximize consumers' benefits and meets the original expectations of retail brands. This recommendation will be finally relevant for Monoprix since the firm will launch a new low price range (at the end of 2015), namely "P'tit prix" (similar as Essential Waitrose, Tesco Value or Sainsbury's Basics). The objective (of those 200 low price products) is to improve the retailer price image. Our research confirms the importance for retailers (mass market) to maintain efforts on this variable even though the global positioning is value-oriented. 
3) In the case of Marque Repère, it seems crucial to focus on the perceived quality of the brand. According to our results, Marque Repère doesn't maximize its value for money. Actually, the perceived quality and packaging destroy its brand equity. In addition, the qualitative dimensions (perceived quality and packaging) of the Marque Repère could be a priority for development.

\section{Acknowledgements}

The author thanks Jean-Marc Ferrandi for giving valuable advice.

\section{References}

[1] Quelch, J.A. and Harding, D. (1996) Brands versus Private Labels: Fighting to Win. Harvard Business Review, 74, 99-109.

[2] Lamey, L., Deleersnyder, B., Dekimpe, M.G. and Steenkamp, J.B.E. (2007) How Business Cycles Contribute to Private-Label Success: Evidence from the United States and Europe. Journal of Marketing, 71, 1-15. https://doi.org/10.1509/jmkg.71.1.1

[3] Meza, S. and Sudhir, K. (2010) Do private labels Increase Retailer Bargaining Power? Quantitative Marketing and Economics, 8, 333-363.

https://doi.org/10.1007/s11129-010-9085-9

[4] Burt, S. and Davies, K. (2010) From the Retail Brand to the Retailer as a Brand: Themes and Issues in Retail Branding Research. International Journal of Retail and Distribution Management, 38, 865-878. https://doi.org/10.1108/09590551011085957

[5] Kumar, N. and Steenkamp, J.-B.E.M. (2007) Private Label Strategy. Harvard Business School Press, Boston.

[6] Corstjens, M. and Lal, R. (2000) Building Store Loyalty through Store Brands. Journal of Marketing Research, 37, 281-291.

https://doi.org/10.1509/jmkr.37.3.281.18781

[7] Beristain, J.J. and Zorrilla, P. (2011) The Relationship between Store Image and Store Brand Equity: A Conceptual Framework and Evidence from Hypermarkets. Journal of Retailing and Consumer Services, 18, 562-574. https://doi.org/10.1016/j.jretconser.2011.08.005

[8] Calvo-Porral, C. and Lévy-Mangin, J-P. (2014) Determinants of Store Brands' Success: A Cross-Store Format Comparative Analysis. International Journal of Retail and Distribution Management, 42, 595-612. https://doi.org/10.1108/IJRDM-04-2013-0085

[9] Diallo, M.F., Coutelle-Brillet, P., Rivière, A. and Zielke, S. (2015) How Do Price Perceptions of Different Brand Types Affect Shopping Value and Store Loyalty? Psychology and Marketing, 1-15. https://doi.org/10.1002/mar.20851

[10] Gonzales-Benito, O., Martos-Partal, M. and Fustinoni-Venturini, M. (2015) Brand Equity and Store Brand Tiers: An Analysis Based on an Experimental Design. International Journal of Market Research, 57, 73-94. https://doi.org/10.2501/IJMR-2015-006

[11] Jara, M. and Cliquet, G. (2012) Retail Brand Equity: Conceptualization and Measurement. Journal of Retailing and Consumer Services, 9, 140-149. https://doi.org/10.1016/j.jretconser.2011.11.003

[12] Cuneo, A., Lopez, P. and Yagüe, M.J. (2012) Measuring Private Labels Brand Equity: A Consumer Perspective. European Journal of Marketing, 46, 952-964. 
https://doi.org/10.1108/03090561211230124

[13] Swoboda, B., Haelsig, F., Schramm-Klein, H. and Morschett, D. (2009) Moderating Role of Involvement in Building a Retail Brand. International Journal of Retail and Distribution Management, 37, 952-974. https://doi.org/10.1108/09590550910999370

[14] Keller, K.O., Dekimpe, M.G. and Geyskens, I. (2016) Let Your Banner Wave? Antecedents and Performance Implications of Retailers' Private-Label Branding Strategies. Journal of Marketing, 80, 1-19. https://doi.org/10.1509/jm.15.0154

[15] Martos-Partal, M. and Gonzales-Benito, O. (2011) Store Brand and Store Loyalty: The Moderating Role of Store Brand Positioning. Marketing Letters, 22, 297-313. https://doi.org/10.1007/s11002-010-9126-x

[16] Farquhar, P.H. (1989) Managing Brand Equity. Marketing Research, 1, 24-33.

[17] Aaker, D. (1991) Managing Brand Equity. The Free Press, New York.

[18] Keller, K.L. (1993) Conceptualizing, Measuring, and Managing Customer-Based Brand Equity. Journal of Marketing, 57, 1-22. https://doi.org/10.2307/1252054

[19] Binninger, A.S. (2007) Les fondements psychologiques et relationnels des marques de distributeurs dans la distribution alimentaire. Décisions Marketing, 45, 47-57.

[20] Dimitriadis, S. (1993) L'extension des marques et des enseignes: Cadre conceptuel et problématique managériale. Recherche et Applications en Marketing, 8, 21-44. https://doi.org/10.1177/076737019300800302

[21] Park, H.H., Jeon, J.O. and Sullivan, P. (2015) How Does Visual Merchandising in Fashion Retail Stores Affect Consumers' Brand Attitude and Purchase Intention? International Review of Retail, Distribution and Consumer Research, 25, 87-104. https://doi.org/10.1080/09593969.2014.918048

[22] Kremer, F. and Viot, C. (2004) Contribution des MDD à l'image de l'enseigne. Journée de l'Association Française du Marketing, Paris, Ecole Supérieure des Affaires, 1-23.

[23] Batra, R. and Sinha, I. (2000) Consumer-Level Factors Moderating the Success of Private Label Brands. Journal of Retailing, 76, 175-191.

https://doi.org/10.1016/S0022-4359(00)00027-0

[24] DelVecchio, D. (2001) Consumer Perceptions of Private Label Quality: The Role of Product Category Characteristics and Consumer Use of Heuristics. Journal of Retailing and Consumer Services, 8, 239-249. https://doi.org/10.1016/S0969-6989(00)00030-8

[25] Dhar, S.K. and Hoch, S.J. (1997) Why Store Brand Penetration Varies by Retailers. Marketing Science, 16, 208-227. https://doi.org/10.1287/mksc.16.3.208

[26] Ngobo, P.-V. (2011) Private Label Share, Branding Strategy and Store Loyalty. Journal of Retailing and Consumer Services, 18, 259-270. https://doi.org/10.1016/j.jretconser.2010.11.007

[27] Jacoby, J., Kyner, D.B. (1973) Brand Loyalty vs. Repeat Purchasing Behavior. Journal of Marketing Research, 10, 1-9. https://doi.org/10.2307/3149402

[28] Oliver, R. (1999) Whence Consumer Loyalty. Journal of Marketing, 63, 33-44. https://doi.org/10.2307/1252099

[29] Zeithaml, V.A, Berry, L.L. and Parasuraman, A. (1996) The Behavioral Consequences of Service Quality. Journal of Marketing, 60, 31-46. https://doi.org/10.2307/1251929

[30] Zeithaml, V.A., (1988) Consumer Perceptions of Price, Quality, and Value: A Means-End Model and Synthesis of Evidence. Journal of Marketing, 52, 2-22. 
https://doi.org/10.2307/1251446

[31] Rondan Cataluna, F.J., Navarro Garcia, A. and Phau, I. (2006) The Influence of Price and Brand Loyalty on Store Brands versus National Brands. The International Review of Retail, Distribution and Consumer Research, 16, 433-452. https://doi.org/10.1080/09593960600844236

[32] Wold, H. (1982) Soft Modeling: The Basic Design and Some Extensions. In: Jöreskog, K.G. and Wold, H., Eds., System under Indirect Observation, North-Holland, Amsterdam, 1-54.

[33] Tenenhaus, M., Vinzi, V.E., Chatelin, Y.-M. and Lauro, C. (2005) PLS Path Modelling. Computational Statistics and Data Analysis, 48, 159-205. https://doi.org/10.1016/j.csda.2004.03.005

[34] Lamberti, G., Aluja, T.B. and Sanchez, G. (2016) The Pathmox Approach for PLS Path Modeling Segmentation. Applied Stochastic Models in Business and Industry, 32, 453-468. https://doi.org/10.1002/asmb.2168

[35] Diamantopoulos, A. and Winklhofer, H.M. (2001) Index Construction with Formative Indicators: An Alternative to Scale Development. Journal of Marketing Research, 38, 269-277. https://doi.org/10.1509/jmkr.38.2.269.18845

[36] Fleck, N. and Nabec, L. (2010) L'enseigne: un capital pour le distributeur. Revue Management et Avenir, 38, 14-32. https://doi.org/10.3917/mav.038.0014

[37] Kremer, F. and Viot, C. (2012) How Store Brands Build Retailer Brand Image. International Journal of Retail and Distribution Management, 40, 528-543.

https://doi.org/10.1108/09590551211239846

\section{Appendix: Retail Brand Square Cosines (XLSTAT Software)}

The square cosines indicate the quality of the projection of the brands on the axes. The following table shows the projection of the Carrefour brand is acceptable on both axes. For Monoprix, only the "original retail brand assets" axis can be interpreted and the projection of the Marque Repère can be assessed only on the "value for money" axis.

\begin{tabular}{ccc}
\hline & Original retail brand assets & Value for money \\
\hline Leclerc & 0.034 & 0.966 \\
Monoprix & 0.890 & 0.110 \\
Carrefour & 0.576 & 0.424
\end{tabular}

